\title{
Moral Emotions, Antiheroes and the Limits of Allegiance
}

\author{
Alberto N. García
}

\section{Introduction}

According to its creator, Vince Gilligan, Breaking Bad (AMC, 2008-13) describes the moral corruption of a normal man, the conversion of Mr. Chips to Scarface. In 'Full Measures' (3.13), the moral and emotional complexity of the story is encapsulated in a seemingly incidental scene. We see Walter White in his living room, giving little Holly a bottle of milk. A close up shows how the baby grabs at his glasses, and in this moment of paternal tenderness, the writers cunningly re-humanize a character who just executed two thugs and minutes later ordered the death of his lab partner, as if to remind us that, at heart, 'he's really just a family man' forced by circumstances to take matters into his own hands. This important step in the metamorphosis of Walter is again mitigated by several factors: children, the family and everyday domestic life. Self-defence is of course the justification for these deaths, but the devotion of a father towards his little baby also enter into the moral and emotional equation that characterises Breaking Bad.

Like AMC's acclaimed hit, many contemporary series_-especially those on cable $\mathrm{TV}$ - are full of characters that we love, broadly speaking, despite the many vile actions they have committed: Tony Soprano, Nancy Botwin, Don Draper, Jackie Peyton and Al Swearengen. This surge in the popularity of antiheroes as protagonists-one of the defining trends of the contemporary golden age of TV fiction-is the focus of this article, a trending topic also in television studies, as shown by recent volumes (Martin; Lotz; Donelly; Vaage, The Antihero). 
Pre-copy-edited version of "Moral Emotions, Antiheroes and the Limits of Allegiance", in Emotions in Contemporary TV Series, García, Alberto N. (eds), Palgrave McMillan, Basingstoke, 2016, pp. 52-70. (See Springer website)

Following the tradition of cognitive media theory, the main thesis of this article is that TV fiction, given its serialized nature, is better equipped to develop a 'structure of sympathy' (Smith, Engaging Characters 5) that allows us to identify with morally defective characters who- beyond some obvious virtues — commit crimes, abuse and deceive; the type of person that would repel us in real life. As will be discussed, the possibility of expanding a story over many hours allows the construction of an emotional structure that 'forces' us to sympathise with protagonists who are not only dramatically complex, but also morally contradictory. Furthermore, following Eaton, our reasoning is that we need certain contradictory, moral emotions in order to properly enjoy these TV series (290). In other words, what we will investigate is how this moral contradiction influences the narrative engine of many of TV's most influential contemporary series, while unravelling both the emotional responses demanded of the viewer and the limits confronting this 'structure of sympathy' that must be continuously reinforced.

To answer these questions, this article will be structured according to four sections: first, we will examine the rise of antiheroes over the past decade, exploring the ideological, industrial and narrative reasons that explain their success. Secondly, we will address how spectators engage morally and emotionally with the moving image, paying special attention to the specific nature of TV narrative. Thirdly, we will analyse the four main dramatic strategies that strengthen our identification with these morally conflicted characters: moral comparatism, the soothing power of family, acts of contrition and victimization. Lastly, we will propose a discussion over the 'levels of engagement' described by Smith and expanded by Vaage for television, in order to explore what the limits of sympathetic allegiance are, and how both the spectator and the narrative need to recover it cyclically. 
Pre-copy-edited version of "Moral Emotions, Antiheroes and the Limits of Allegiance", in Emotions in Contemporary TV Series, García, Alberto N. (eds), Palgrave McMillan, Basingstoke, 2016, pp. 52-70. (See Springer website)

\section{The emergence of antiheroism in contemporary TV}

There are different reasons — ideological, industrial and narrative — that explain the current trend of antihero protagonists in contemporary television, but first we must acknowledge that the definition of an antihero may be overly broad. Authors such as Frye describe antiheroes as ironic heroes, 'inferior in power or intelligence to ourselves, so that we have the sense of looking down on a scene of bondage, frustration or absurdity' (151). However, the most common type of the antihero of more recent times is closer to the Byronic hero or the 'rogue hero' referred to by Hume (246). Instead of mediocre and listless, the predominant traits of today's antihero are a mixture of hero and villain characterised by moral ambiguity; a certain Machiavellianism exists with regards to the achievement of certain ends, and a contradiction between ideals (if the hero possesses any) and actions. Generally, as Shaffer and Raney write, antiheroes are 'criminal but redeemable [...]. Despite clearly engaging in improper actions for (at times) corrupt reasons, antiheroes still function as "forces of good" in many narratives' (1030). As we will see, being 'forces of good' is essential to identifying with the characters; but, as we discuss in the last section, a character can also change and be perceived as a 'force of evil' as the narrative progresses.

To explain the emergence of so many antiheroes in today's television, we must first consider an ideological issue: postmodernism cultivates anti-heroism. 'The problem', writes McCaw, 'is that coherent, diagnosable notions of profound moral transgressions rely, perhaps self-evidently, upon some form of consensus as to the social norms and values that are being transgressed' (23-4). As the fragmentation of contemporary, post-1968 Western societies has provoked a collapse in moral and political consensus, there is now an intellectual substrata guided by moral relativism 
Pre-copy-edited version of "Moral Emotions, Antiheroes and the Limits of Allegiance", in Emotions in Contemporary TV Series, García, Alberto N. (eds), Palgrave McMillan, Basingstoke, 2016, pp. 52-70. (See Springer website)

that has given rise to the idea of good and evil — central themes in classical heroismbeing replaced by cynicism and contradiction. The mainstream has been taken over by a pessimistic and defeatist intellectual atmosphere and this has influenced TV fiction.

Secondly, there is the nature of the entertainment industry itself: consider that cable TV has always sought to differentiate itself from traditional networks; this has generated a virtuous circle whereby competition has spurred artistic and aesthetic vitality. If HBO led the charge with The Sopranos (1999-2007), Showtime followed in its footsteps, exploring the sympathetic antihero with Weeds (2005-12) or Dexter (200613). If FX showed that a corrupt and criminal police force (The Shield, 2002-08) could earn the applause of the audience, AMC emulated them with Drapers and Whites. Even the traditional network channels 'retaliated' by offering prominent examples of antiheroes, such as Jack Bauer in 24 (Fox, 2001-), Benjamin Linus in Lost (ABC, 200410) or Gregory House in House M.D (Fox, 2004-12). This elevation of the antihero as a paradigm of high quality television combines ideological and entrepreneurial elements in order to generate a thematic constant that can be effectively developed in a serial narrative.

This trend is unprecedented. While there were many excellent series 20 years ago (though not as many as now), anti-heroism was the exception ${ }^{1}$ and not the rule in the most influential shows. ${ }^{2}$ This is not to say that only contradictory protagonists who are part hero and part villain generate quality drama. For example, in The X-Files (Fox, 1993-2002), the protagonists, who adhered to the traditional heroic profile, experienced many internal and external conflicts but they never ceased to be positive characters. They were morally exemplary, courageous in the face of adversity, and willing to sacrifice themselves for the greater good of society; the villains were identified and corruption was uncovered in the institutions, however, Mulder and Scully were above 
Pre-copy-edited version of "Moral Emotions, Antiheroes and the Limits of Allegiance", in Emotions in Contemporary TV Series, García, Alberto N. (eds), Palgrave McMillan, Basingstoke, 2016, pp. 52-70. (See Springer website)

corruption or vice. This is also evident in contemporary network television programs: for example, while The West Wing (NBC, 1999-2006), Lost and The Good Wife (CBS, 2009-) feature dramatically rich characters, they lack the essential moral equivocation that defines the protagonists of contemporary cable TV series. From $O z$ (HBO, 19972003) to Ray Donovan (Showtime, 2013-), anti-heroism has been a key dramatic element and the internal contradictions of the protagonists serve as a seed from which the deepest conflicts of the story develop.

The third reason that explains the current trend of TV antiheroes is related to the notion of an expanded, protracted narrative that is a feature of so many cable shows. Series like these (that is, ones which have taken this quasi-novelistic approach) have redefined the notion of quality television drama. The complex network of characters, relationships, political alliances, bloodlines and all kinds of conflicts that exist in series, such as Deadwood (HBO, 2004-06), The Wire (HBO, 2002-08) and Game of Thrones (HBO, 2011-), would have been unfeasible a few decades ago. These artistically ambitious series can develop over 10 storylines per episode, using a boundless narrative flow that reminds us of writers from the nineteenth century. Moreover, by using more footage to develop the plot-without the need to waste time repeating plots and motifs, as was the style of earlier series or current self-contained narratives - the conflicts and dilemmas multiply, enriching the moral, emotional and political diversity of the story. This 'complex-TV', as Mittel has coined it (forthcoming), has produced a remarkable effect on our emotional engagement with dubious characters, such as the many 'bad boys' referred in this article. We will return to the importance of the story in addressing the limits of our allegiance in the last section of this article. It is now necessary to take a closer look at what the different levels of engagement for the spectator are, so that we 
Pre-copy-edited version of "Moral Emotions, Antiheroes and the Limits of Allegiance", in Emotions in Contemporary TV Series, García, Alberto N. (eds), Palgrave McMillan, Basingstoke, 2016, pp. 52-70. (See Springer website)

can understand how moral emotions come into play in the consumption of television fiction.

\section{Moral emotions and character engagement in TV}

Like cinema, televised fiction is explicitly and implicitly emotional. To narrate is to produce emotions. As Ed Tan explains, 'films are designed to produce a particular effect and as an artifact, they display a functional design and develop a certain consistency. This orderly structure and consistency are both reflected in the systematic affective reaction of the viewer, a reaction that they themselves are not aware of' (3). In the same vein, Carroll emphasises the emotional determinism of commercial audiovisual fiction, which is designed to generate a specific emotional response: 'Fiction film events have been emotionally predigested for us by filmmakers [...]. The filmmakers have selected out the details of the scene or sequence that they think are emotively significant and thrust them, so to speak, in our faces' (Engaging the Moving 29). Consequently, the series discussed here are 'emotionally predigested for us' so that we sympathise and identify with the characters - antiheroes - that combine admirable traits (professionalism, intelligence, courage) with other less savoury characteristics (violence, meanness, deceit, cruelty).

At this point, a semantic clarification is needed around the term 'sympathy' and 'empathy'. As Neill emphasises, 'with sympathetic response, in feeling for another, one's response need not reflect what the other is feeling, nor indeed does it depend on whether the other is feeling anything at all'. On the other hand, 'in responding empathetically to another, I come to share his feelings, to feel with him; if he is in an emotional state, to empathize with him is to experience the emotion(s) that he experiences' (175-6). In any case, the relevant issue for our reasoning is that feeling 
Pre-copy-edited version of "Moral Emotions, Antiheroes and the Limits of Allegiance", in Emotions in Contemporary TV Series, García, Alberto N. (eds), Palgrave McMillan, Basingstoke, 2016, pp. 52-70. (See Springer website)

sympathy or empathy for a character is less risky than in real life because we, as spectators, can project a 'safety net' that allows us to admit some traits in fiction that we would not in real life (Vaage, 'Fictional Reliefs'; Keen 220).

At first glance, identification with a character seems to be facilitated by certain elements, whether it is the protagonist's professional efficacy (Omar Little, Francis Underwood), courage in the face of adversity (Spartacus, Tony Soprano), ingenuity (Walter White, Gregory House), or, as Mittel puts it, the charisma of the actor portraying the character and the character him/herself (Don Draper/John Hamm, Tom Kane/Kelsey Grammer): 'A sense of charm and verve that makes the time spent with them enjoyable, despite their moral shortcomings and unpleasant behaviours'. However, further analysis reveals that these elements are subordinate to what Murray Smith called 'levels of engagement'. Smith makes a distinction that helps us to understand the moral judgment and attitudes of the viewer towards characters. He highlights—-beyond what he himself calls 'recognition' — two narrative/dramatic processes, alignment and allegiance: the first being a feature of the film, while the latter is an audience response provoked by the audiovisual work.

First, alignment (a similar concept to Genette's 'focalization') 'concerns the way a film gives us access to the actions, thoughts, and feelings of characters' (Engaging Characters 6). Consequently, we align with a character through a 'spatio-temporal relationship' (that is, the story shows what the character does in his/her environment) and a 'subjective access' (the story reveals how the character feels and what they desire). Except for ensemble casts such as The Wire and Deadwood, most of the series, which this article focuses on, present a clear protagonist, whom we follow and, consequently, with whom we align, through both their domestic and professional lives. 
Pre-copy-edited version of "Moral Emotions, Antiheroes and the Limits of Allegiance", in Emotions in Contemporary TV Series, García, Alberto N. (eds), Palgrave McMillan, Basingstoke, 2016, pp. 52-70. (See Springer website)

Meanwhile, allegiance "concerns the way a film attempts to marshal our sympathies for or against the various characters in the world of fiction' (Engaging Characters 6). Through this process, the character gains the viewer's approval, a complicity that Plantinga also describes as being 'rooted in the spectator's evaluation of the moral traits of a character. The spectator will be led to sympathise with a character who is held to have morally desirable traits. Such sympathies, in turn, partly determine the emotional responses of spectators to the narrative situations of the film' ('I Followed' 37). This is not to say that our allegiance is unconditional. Our ability to feel sympathy for these characters is not unlimited and can be combined with contempt for immoral or violent actions, or as we will discuss later, can result in a dramatic turnaround in our relationship with them.

It may be interesting to mention here the distinction that Plantinga establishes between mere 'sympathy' towards a character and the more solid concept of 'allegiance': 'We might consider sympathy to be more flexible and protean than allegiance, and its causality more diffuse and unpredictable. We might consider allegiance - our allying ourselves with, focusing on, rooting for a character - to be a relationship established only after appropriate narrative and character development' ('I Followed' 41). Thus, 'allegiance' implies a long-term investment in the character, something that serial fiction is in a privileged manner to allow. In this environment, it is easier for us to reconcile with the characters when they commit unpleasant acts that distance them from us emotionally.

In this sense, it is also important to take into account that our engagement with TV characters is slightly different than our engagement with film characters. As Blanchet and Vaage have stated, TV narrative 'activates some of the same mental mechanisms as friendship does in real life' (28). Consequently, 'television series are better equipped to 
Pre-copy-edited version of "Moral Emotions, Antiheroes and the Limits of Allegiance", in Emotions in Contemporary TV Series, García, Alberto N. (eds), Palgrave McMillan, Basingstoke, 2016, pp. 52-70. (See Springer website)

allow spectators to develop a bond with fictional characters than feature films. This is because television series more effectively invoke the impression that we share a history with their characters: first, because of the series' longer screen duration and, second, because our own lives progress as the series goes on' (28). That means that alignment (that is, familiarity with the actions of a character) provokes allegiance (that is, partiality in our moral consideration of this character's actions). An obvious example of this would be that of Dexter Morgan and his overwhelming use of voice over, which facilitates our allegiance a priori to a despicable character, because it allows us to become close to him. He verbalizes his doubts, laughs at himself, and explains both his modus operandi and the justification for, and limits of, his bloody deeds (Harry's code). In this way, the serial killer's murders are placed in a much more benign, understandable and domestic context for the viewer.

A serial killer (Dexter) and a sophisticated cannibal like Dr Lecter can produce a 'perverse allegiance' within us (Smith, 'Gangsters, Cannibals'). As explained by Carroll, the moral judgment we form in response to audiovisual fiction is largely influenced by emotional responses, and therefore can be manipulated: '[We] tend to think of moral judgments as being issued after a chain of reasoning. However, [...] Moral judgments are generally fast, automatic, intuitive appraisals; in short, they are emotions' ('Movies, the Moral Emotions' 8). An example can serve to illustrate this point: in the infamous gastronomic/musical sequence of 'Sorbet' (1.7), the operatic rhythm provides a festive atmosphere and accentuates Dr Lecter's passion for the kitchen in Hannibal (NBC, 2013-). Moreover, together with the delicate surroundings and the stylized, sterilized environment, the music 'absolves' the cannibalistic Lecter by forcing the viewer to admire this gastronomic symphony, and the pleasure with which the elegant psychiatrist so gently handles the 'ingredients'. The melody then ends in 
Pre-copy-edited version of "Moral Emotions, Antiheroes and the Limits of Allegiance", in Emotions in Contemporary TV Series, García, Alberto N. (eds), Palgrave McMillan, Basingstoke, 2016, pp. 52-70. (See Springer website)

order to invert the dynamic of evil: instead of being pleasant and familial, the scene takes on strange, abominable nuances, and the rhythmic sequence is revealed for what it is: the preparation of human organs as a refined domestic task.

\section{Dramatic strategies}

The Hannibal example cited above demonstrates the enormous emotional power of the moving image, filled with 'emotional markers' (Vaage, 'Fiction Film' 169). The emotional identification/moral judgment that we are dealing with here is not only produced by the plot, but also by the mise-en-scène itself: the musical background, extended close-ups, epic slow motion scenes, symbolic lighting, unusual camera angles, magnetic performances and intimate voice overs. However, these formal, aesthetic resources are not enough to incline us in favour of the ambiguous protagonist, nor root for him. The mise-en-scène can reinforce, rather than create, such strong allegiances. Therefore, fictional TV drama needs some dramatic strategies to ensure that the viewer maintains an overall positive emotional attitude towards the protagonist: the perversity of the antagonists, the presence of family, acts of contrition and the victimization of the character. These are the four dramatic strategies that allow the narrative to "criterially pre-focus' (Carroll, 'Film, Emotion' 30) our emotional reactions, strengthening our allegiance to a particular character and avoiding the negative moral evaluation that would occur in real life.

\subsection{Moral comparatism and the lesser evil}

During the third episode of True Detective (HBO, 2014-), State Homicide Detective Martin Hart enquires of his quiet and mysterious partner: 'You ever wonder if you are a bad man?' Rust Cohle answers coldly: 'No, I don’t wonder, Marty. The world needs 
Pre-copy-edited version of "Moral Emotions, Antiheroes and the Limits of Allegiance", in Emotions in Contemporary TV Series, García, Alberto N. (eds), Palgrave McMillan, Basingstoke, 2016, pp. 52-70. (See Springer website)

bad men. We keep the other bad men from the door'. This dialogue encapsulates the first dramatic strategy employed in making antiheroes likeable: there is always someone much worse than they are. Thus, we side with Dexter Morgan, Nick Brody or Tom Kane of Boss (Starz, 2011-12) because we, sometimes unconsciously, compare them with other characters and reach the conclusion that our protagonists, despite their violent methods, their immoral actions and their crimes, still are 'the good guys'. Therein lies the moral ambiguity that has so vitalized current TV drama: it forces you to choose the 'lesser evil' and, consequently, reinforces our sympathy for the protagonist. Of course, we usually continue to be connected with these characters emotionally and morally as a matter of 'dramatic balance'; the protagonist needs an antagonist. The pilot episode of The Shield visually exposes this moral Machiavellianism. Vic Mackey may be a despicable cop but he is a tremendously effective agent who, lest we forget, is also presented in the first episode in his role as the father of two autistic children who require special care. One of the subplots of the pilot concerns a case of paedophilia. Faced with the imminent death of a kidnapped girl, only Mackey's unorthodox methods can save the child. The closing montage of the pilot visually reinforces the ethical ambiguity that defines the series: we need Mackey out there, doing the dirty work, to enjoy the tranquillity of our own homes. It is no coincidence that in each season-in a dramatic balancing act well planned by the writers - the Strike Team, despite their violent and sometimes illegal methods, need to face villains far more savage and ruthless than they are, and they always win. If, as Carroll argues in relation to Tony Soprano, we look at the 'moral structure' of the fictional world of The Shield, we realise that Vic Mackey 'is far from the worst character'. There is no denying that the leader of the Strike Team is 'morally defective, but only to suggest that among an array of ethically challenged characters, he is one of the least deplorable' ('Sympathy for' 131- 
Pre-copy-edited version of "Moral Emotions, Antiheroes and the Limits of Allegiance", in Emotions in Contemporary TV Series, García, Alberto N. (eds), Palgrave McMillan, Basingstoke, 2016, pp. 52-70. (See Springer website)

32). While this does not make his misdeeds good, it means that the viewer, driven by an emotional identification with characters and the agonising environment in which they are presented, ultimately forms a positive moral evaluation of them upon experiencing events that have been 'emotionally predigested for us'.

\subsection{The family as source of emotional and moral support}

When reflecting on the relationship between dramatic identification and emotion, one must take into account a key element that acts as a powerful buttress: the family. Blood ties destabilize the internal and external moral framework of the antiheroes. On the one hand, the presentation of the family serves as an alibi justifying the need for many of their reprehensible actions; on the other, however, the home environment brings out the best in these characters, their romantic, altruistic or selfless sides. Thus, in series which differ greatly in terms of both genre and theme, the family serves to justify the more reprehensible deeds, while simultaneously allowing us to view these characters in a different light, in an environment in which moral rectitude and the sincerity of their intentions are clear. Thus, although the characters shift their moral compass to ensure the welfare of the family, we tend to empathise with them and convince ourselves of their self-justifications because in the end they do what they do to feed their children (Weeds), to maintain a legacy (Sons of Anarchy) or ensure the survival of their dynasty (Game of Thrones).

Why does family exert such a strong influence in this type of series? Mainly because the serialized story, by its very nature, encourages the combination of the public and private lives of the protagonists, namely their professional lives-usually ${ }^{3}$ the most amoral — with their personal lives, through which we emotionally reconnect with these characters when we watch, for example, how parenting absolves other 
Pre-copy-edited version of "Moral Emotions, Antiheroes and the Limits of Allegiance", in Emotions in Contemporary TV Series, García, Alberto N. (eds), Palgrave McMillan, Basingstoke, 2016, pp. 52-70. (See Springer website)

misdeeds. It would be reductive, given their dramatic complexity, to think that for many of these antiheroic protagonists their families and children are simply an excuse to justify their criminal selves. Rather, the primacy of the family in these TV series serves as a rich source of moral and emotional tension, and as a genuine lifeline for at least some degree of moral redemption. In both scenarios, the family is 'positive' for the character's image, as the presentation of the family environment acts as a moral balm and a powerful trigger of sentimental complicity. To employ an extreme example, it is a mechanism used in Boardwalk Empire (HBO, 2010-14) to humanize the sadistic megalomaniac character of Al Capone: Capone's sweetness with his deaf son 'reduces' the mobster's evil in the eyes of the beholder, preventing his transformation into a cartoon villain. This strategy of 'sweetening' the character's evil deeds by showing their intimate domestic life is in no way unique to television fiction (see Moltke). However, as discussed later, the technique involves some unique features in a serialized storynot in the self-contained stories but rather in those that develop a powerful and extensive background plot—which favours a certain ambiguity in the life of the characters with which we align.

\subsection{Acts of contrition}

Smith has written an essay where he discusses the audience's moral identification with Tony Soprano around a violent incident of 'Mr. And Mrs. John Sacrimoni Request' (6.5). In that episode, Tony beats one if his subordinates for no apparent reason. Afterwards, he feels bad and goes to the bathroom to vomit: 'Soprano's guilt reveals him to be a moral being even as it drives him to further deplorable acts' ('Just What' 77). A similar situation occurs in episode 2.9 ('Martial Eagle') of The Americans: after being forced to murder an innocent truck driver, Philip Jennings wanders through the 
Pre-copy-edited version of "Moral Emotions, Antiheroes and the Limits of Allegiance", in Emotions in Contemporary TV Series, García, Alberto N. (eds), Palgrave McMillan, Basingstoke, 2016, pp. 52-70. (See Springer website)

rest of the episode, tormented by guilt. In both cases, the guilt recasts these characters as 'morally sentient' beings in our eyes and, consequently, allows us to acknowledge them, despite their villainy, as 'one of ours' (Smith, 'Just What').

According to Lindsay-Hart et al., 'the psychological situation of guilt involves a violation of the moral order, for which we take responsibility. The primary motivational instruction of guilt is the felt desire to "set things right", to restore the balance in moral order' (289). Consequently, in assuming their share of blame, many of the anti-heroes analysed in this article achieve the attenuation of their sins from the audience, winning back their moral sympathy and restoring damaged allegiances. Demonstrations of moral scruples make them morally and emotionally desirable once again, and even allow them to employ the last of the strategies that feeds our allegiance to them as anti-heroes: the strategy of victimization.

\subsection{Character victimization}

Upon apologising and/or feeling guilt, we assume the following characters have acted wrongly: Shane Vendrell in order to save his family in The Shield; Philip Jennings in making an outdated political commitment in The Americans; and Nucky Thompson because of an unforgivable sin of youth in Boardwalk Empire. We regard them as victims of circumstance, who suffer the consequences of bad decisions made in the past. According to Platinga, 'we sympathise with characters when we believe that they are in danger and must be protected, when they are suffering or bereaved, or when we believe that someone has been treated unfairly' ('I Followed' 41). It is what iconic series such as Breaking Bad and The Sopranos do with their protagonists, in the early stages of their stories. The pilot of each episode makes a dramatic effort to locate their protagonists as victims: in the case of Breaking Bad, Walter and Jesse are cast as born 
Pre-copy-edited version of "Moral Emotions, Antiheroes and the Limits of Allegiance", in Emotions in Contemporary TV Series, García, Alberto N. (eds), Palgrave McMillan, Basingstoke, 2016, pp. 52-70. (See Springer website)

losers, while The Sopranos portrays a man suffering under the stress of his work and family responsibilities, with a guilt complex created by his mother, and psychologically damaged to the point of needing medical help. As a result, from the very beginning, we are presented with a situation that demands our allegiance, generating a 'structure of sympathy' (Smith, Engaging Characters 5) that predisposes us emotionally, and as a consequence morally, towards this entire array of characters. Despite the clear differences, we can also apply this same 'moral gap' to Dexter. The main character is also, at heart, a victim, as his 'urge to kill' comes from a bloody and traumatic childhood episode in which his mother was killed in front of him. Dexter is not, therefore, guilty of his evil deeds, as they do not stem from his own conscious decisions.

In all these cases, a sense of no escape plays a role in the victimization of the protagonist; they have to carry out these morally reprehensible actions because they cannot do anything else given the situation in which they find themselves. Many of these TV series convey the feeling that violence is the inevitable last resort, thus diminishing the responsibility of the protagonists, perceived as victims of their circumstances. However, this absolution has its limits. As mentioned above, the serialized format helps the viewer to identify with the protagonist, at times even going back to square one. There are unforgivable acts that cause the viewer to question seriously_ or even lose - their sympathetic allegiance with the protagonist.

\section{The limits of sympathetic allegiance}

The novelty introduced by American cable TV series, as compared with films, is that they question our allegiance to the protagonists as a way of constantly renewing our dramatic and narrative interest. It allows the writers to advance the plot, build suspense 
Pre-copy-edited version of "Moral Emotions, Antiheroes and the Limits of Allegiance", in Emotions in Contemporary TV Series, García, Alberto N. (eds), Palgrave McMillan, Basingstoke, 2016, pp. 52-70. (See Springer website)

and repeatedly renew dramatic conflicts, as TV's expanded narrative structure demands. The protagonists have to cyclically revive the sympathy we feel for them, despite the sins they commit, so that these conflicts can multiply and the story can expand dramatically over the course of several seasons, without being repetitive.

A dramatically rich antihero can carry out good deeds, questionable actions and even despicable acts. The key to the alliance between the viewer and the character is that we judge these antiheroic protagonists with a degree of goodwill. We create our own value system with which to approach a fictional story. In short, we establish a specific 'moral covenant', adapting our moral judgment to the characters we like. As previously suggested, sympathy for a character is not only evoked because they exhibit exemplary ethical behaviour; rather, as Smith maintains 'moral evaluation lies at the core of allegiance', constituting 'a kind of centre-of-gravity that amoral factors may inflect, but not displace' ('Just What' 84). As is evident in many of the protagonists discussed in this article, they all commit horrific acts and yet we remain committed to them, feeling emotionally close to them. However, for how long? Are there limits that can suspend our allegiance to a sympathetic protagonist? If so, is it possible to recover that allegiance later? If so, how?

\subsection{Cyclical re-allegiance}

As part of their narrative and dramatic evolution, the dark side of many TV antiheroes comes to the fore as the story progresses. This is seen with Rick Grimes (in his biblical confrontation with Shane in The Walking Dead, AMC, 2010-), Nucky Thompson (who shoots his former disciple and surrogate son) and the Jennings couple in The Americans (who murder innocents while accomplishing their undercover missions), to name but a few. 
Pre-copy-edited version of "Moral Emotions, Antiheroes and the Limits of Allegiance", in Emotions in Contemporary TV Series, García, Alberto N. (eds), Palgrave McMillan, Basingstoke, 2016, pp. 52-70. (See Springer website)

In order to reflect on the limits of this 'structure of sympathy' that is generated around the television antiheroes, we can start from the aforementioned beating of a subordinate by Tony Soprano, an example discussed in depth by Smith. In his article, Smith developed the term 'partial allegiance' as an expansion of his original structure of sympathy: 'We ally ourselves with some of his attitudes and not others; indeed, some of his actions and attitudes draw our antipathy rather than sympathy' ('Just What' 86). This conflicting, ambivalent allegiance is precisely what fuels the plot in the high-end TV series we are analysing here. Along the same lines, Mittel refers to the complex and often contradictory feelings that Walter White's actions provoke in the spectator 'operational allegiance'. Both Smith and Mittel confer with Vaage's arguments in her recent article (2014) on the proliferation of anti-heroes: the three refer to the limits of 'allegiance'. However, the three authors maintain, with different nuances, that while sympathetic allegiance may suffer occasional deterioration, overall, it remains intact. My intention here is to question their argument and to affirm that it is precisely the length of the serial story and the viewer's memory that allows us to gauge the accumulation of evil caused by a character until causing us to lose sympathy for him. Consequently, the aforementioned strategies will be necessary in order to achieve the viewer's 're-allegiance' with the character. That is, sympathetic allegiance must be nourished to remain effective; the 'structure of sympathy' is not indestructible once established in the early stages of the story. Therefore, what Smith calls "partial allegiance' could be more accurately labelled as a 'cyclical re-allegiance'; that is, the story has to constantly make a dramatic effort to relocate our sympathetic allegiance. As Vaage explains, 'we become partial towards the character we know best' ('Blinded by' 269), to a point where the familiarity of a story which spans several years 'blinds' us when evaluating their actions: 'As spectators of fictions, we rely more 
Pre-copy-edited version of "Moral Emotions, Antiheroes and the Limits of Allegiance", in Emotions in Contemporary TV Series, García, Alberto N. (eds), Palgrave McMillan, Basingstoke, 2016, pp. 52-70. (See Springer website)

strongly on moral emotions than on moral reasoning' (274). Vaage emphasises the artistically pleasurable contradiction that the engagement with stories the viewer is emotionally committed to brings, and the tension created when the viewer reflects coldly on the morality of their actions. Vaage states: 'When the narrative explicitly reminds us of the consequence of their actions, we may drift out of sympathy momentarily, but, once the narrative moves on, we tend to bounce back into sympathetic allegiance' (280). My point is that the narrative needs to 'move on' with an explicit act of re-allegiance.

Therefore, without denying the validity of Vaage's reasoning, it seems necessary to add an additional twist: not only do the stories regularly test our sympathy for the antihero, but the possibility exists that they can make you lose all of that sympathy gradually. Therefore, after a violent or immoral act, the viewer needs one of the strategies previously cited in order to 're-establish' their sympathy for the character. It occurs in the tender scene in Breaking Bad, which was described at the beginning of this article, and Tony Soprano's vomiting after leaving his subordinate badly injured. It is a constant need; otherwise, the viewer's sympathetic allegiance may be lost, as happens in certain cases, since the accumulation of evil and the viewer's memory, despite the emotional balances we have described, can erode the moral sympathy of the viewer to such an extent that the 'oscillating sympathy structure in the series' (Vaage, 'Blinded by' 277) can result in aversion or dislike of a character.

In Breaking Bad, for example, our complicity with Walter falters during the first half of the fifth season, when he terrorises Skyler, kills Mike, and is unfazed by the death of the boy on a bike. Furthermore: with Gus Fring liquidated, there is no villain in the story worse than him; there is no counterweight. Therefore, it is doubtful that our sympathies for Walter, which at that point in the story had lasted a calendar year for 
Pre-copy-edited version of "Moral Emotions, Antiheroes and the Limits of Allegiance", in Emotions in Contemporary TV Series, García, Alberto N. (eds), Palgrave McMillan, Basingstoke, 2016, pp. 52-70. (See Springer website)

regular viewers of the show, would remain unchanged. Of course, as spectators, we are anxious to know how Walter White's journey will end (mostly due to the flash forward scene in episode 5.1 which suggests that his end will be tragic and violent), but from the standpoint of emotional identification, part of the critical discussion about the series had to do with tempering the tendency to 'root for Walt' (Zoller Seitz).

Precisely because our allegiance is very problematic after episode 5.8, one of the principal dramatic objectives of the last eight episodes of Breaking Bad is the rehumanization of Walter, the reconstruction of our emotional identification with him and, ultimately, our 're-allegiance'. It does so using the four strategies mentioned in the previous section: first, a new group of despicable villains emerges (Todd's familiar neonazis) before which even Walter, despite his considerable degree of villainy at this point in the story, is presented as 'morally preferable'. Secondly, his cancer returns and because of his physical frailty, he once again becomes a victim in our eyes, someone weak and powerless ('Granite State', 5.15, is a key episode in achieving this effect for the last time). Thirdly, his lack of scruples collides with a clear moral line: the family is untouchable. The latter is seen not only by his genuine grief after the death of Hank, but by his return of Holly (placing the good of the girl before his selfishness). It is precisely with Hank's death, as with so many of the deaths Walter causes, that the last of the strategies of 're-allegiance' appears: the strong sense of guilt, but as usual Walter fools himself once again in order to convince himself of his innocence. Something similar happens at the end of 'Ozymandias' (5.14), during a phone call between Walter and Skyler, where tears are confused with reproach. The viewer empathises with Walter's pain for having ruined everything. Still, as we shall see while explaining 'post-mortem re-allegiance' below, Walter's apology to Skyler in the season finale will be the real act of contrition that will close our circle of emotional identification. 
Pre-copy-edited version of "Moral Emotions, Antiheroes and the Limits of Allegiance", in Emotions in Contemporary TV Series, García, Alberto N. (eds), Palgrave McMillan, Basingstoke, 2016, pp. 52-70. (See Springer website)

The expanded narrative we previously explained favours emotional redemption and, consequently, 're-allegiance' with the characters once we are shown their familial, sentimental and friendly qualities. This is what happens also to Don Draper - in a canonical example of 'cyclical re-allegiance' — after his descent into hell in the sixth season of Mad Men. In the end, his redemption comes through Sally, his daughter, and he ends up with his three children outside the house in which his painful childhood was played out. We see, then, a family man, a loving father after an act of contrition (the Hershey pitch) and, also, the scene depicts the house where he was the victim of a poor and lonely childhood. The nature of the series gives the viewer access to the most intimate qualities of the character, forming a naturalistic, all-encompassing story that aims to capture the wounds of time in the life of the characters. By taking 60 hours instead of two to develop conflicts, the very nature of the story allows us to modulate our anger towards the terrorist, Nick Brody in Homeland: through the warmth of home, we discover both the magnitude of his trauma (victimization) and the love of a father who adores his children. In short, we can recover our sympathy cyclically, precisely because of the specific form, duration and dramatic needs of television narrative.

\subsection{Switching and late allegiance}

The second half of the final season of Breaking Bad exemplifies how, beyond the cyclical re-allegiance after each reprehensible act, the specificity of serial narrative forces a narrative and dramatic effort to restore the 'structure of sympathy' necessary for the moral identification with the protagonist, which makes us 'understand' their complexity and look upon them benevolently or excuse their evil deeds. However, it may happen that as the expanded serial story progresses, our sympathetic allegiance 
Pre-copy-edited version of "Moral Emotions, Antiheroes and the Limits of Allegiance", in Emotions in Contemporary TV Series, García, Alberto N. (eds), Palgrave McMillan, Basingstoke, 2016, pp. 52-70. (See Springer website)

switches sides. This same expanded story format can work out in the opposite way: allowing for the 180-degree turn in our feelings for a character that we initially despise.

It is true that allegiance is more difficult to achieve in series with an ensemble cast, however, the following example will serve to illustrate the idea: after 25 episodes, Jaime Lannister, who is introduced in Game of Thrones via two repulsive acts, incest and the attempted murder of a child, is humanized in the third season by humiliation, amputation and his admission of a tormented secret to his captor (Brienne de Tarth). Therefore, as we align with the character in a more intimate and painful space, it results in a drastic turn-around of our sympathy towards him. Thus, the serial narrative allows internal and external conflicts to multiply, increasing the complexity of these violent antiheroes who are also family men, victims, and, therefore, 'morally sentient'. Therefore, it is not only that familiarity that blinds us, as Vaage argues, but the previously mentioned strategies are also required in order to build that moral sympathy with the hitherto villain, Jaime Lannister. A counterexample to this moral investment in the appreciation of a character might be that of Ben Sherman in Southland (NBC/TNT, 2009-13): from being the moral compass — the impeccable hero — during the first three seasons of the series, his actions become steadily darker and the viewer gradually loses the initial allegiance towards his actions.

However, beyond the 'switching of allegiances' embodied by Jaime Lannister or Ben Sherman, there is still another option: one that might be called 'late allegiance'. It is the riskiest option dramatically, and the one which creates more doubt about the soundness of the 'structure of sympathy' built throughout a storyline. It is an allegiance that, as the story nears its end, moves from a main character who, until then, had held the privilege of sympathetic allegiance to another, secondary character. One case that best exhibits this 'late allegiance' is The Shield, which, lest we forget, starts with 
Pre-copy-edited version of "Moral Emotions, Antiheroes and the Limits of Allegiance", in Emotions in Contemporary TV Series, García, Alberto N. (eds), Palgrave McMillan, Basingstoke, 2016, pp. 52-70. (See Springer website)

another unforgivable act (a shooting in the pilot episode that will haunt the characters for seven seasons) that lies at the heart of our contradictory emotional identification with Vic Mackey.

As is the case with Breaking Bad, we also end up despising Vic Mackey, whose criminal and heroic selves we learned to balance positively over the course of seasons. Without oversimplifying the moral complexity of the plot and the difficult emotional relationship we establish with the protagonist, it is difficult to maintain our allegiance with Vic Mackey in the last season of The Shield, especially in its later episodes. His confession to Agent Murray, and her terrified face upon coming to understand what type of 'monster' she has negotiated an immunity agreement for, are meta-references for the viewer, who has identified with Mackey throughout The Shield, and who suddenly becomes aware of the accumulation of evil such a character has performed ('Possible Kill Screen', 7.12).

Shane Vendrell's case is an extreme example of how 'late allegiance' can be constructed, thanks to the possibilities of an expanded storyline. The sixth and, especially, seventh season of the series do an extraordinary job of shifting our allegiance from Mackey to Shane. Once more, the four dramatic strategies mentioned above are in operation here: the agonising flight of Shane, and his pregnant wife and two-year-old son making him a victim lashed by the consequences of an evil act attributed to Mackey, as Shane himself recalls in his last written confession. This final letter, unfinished since he shoots himself in the head before completing it, is a supreme act of contrition; in fact, it is essential to his own conscience about the evil he has done and the price to be paid, unlike Mackey, who is still toying with self-justifying excuses. Above all, it is the shelter of his family that manages to win us over to their side and, 
Pre-copy-edited version of "Moral Emotions, Antiheroes and the Limits of Allegiance", in Emotions in Contemporary TV Series, García, Alberto N. (eds), Palgrave McMillan, Basingstoke, 2016, pp. 52-70. (See Springer website)

despite the terrible acts he has committed, to gain our moral sympathy for him and his death, which causes an emotional earthquake unmatched in contemporary television.

The switching and late allegiance in The Shield highlights the changing nature of sympathetic allegiance in serial television storylines. This process is related to what Mittel called 'serial articulation', that 'depends on the practice of reiteration, where repeating and reframing helps define which linkages are maintained and discarded over the course of the series'. It is as if each story counts on a steady flow of sympathy with which creators can feed the dramatic conflicts, so that if a character loses flow, another must acquire it. That is, the moral counterweight other characters make is critical and necessary for maintaining emotional and moral interest in history, so if our allegiance to Vic Mackey and Walter White is lost, there are other characters who take the baton so that the viewer roots for them (for example, Claudette or Shane; Hank or Jesse).

\subsection{Re-allegiance post-mortem}

Before I conclude this reflection on the limits of allegiance, a further possibility may be explored: the way in which re-allegiance is fully recovered upon closure of the television storyline. To paraphrase Kermode's classic book (The Sense of an Ending), the ending provides full sense to a narrative, since, as viewers, we 'interpret' the totality of the story from its end. As Abbott explains, 'all successful narratives of any length are chains of suspense [lack of closure] and surprise that keep us in a fluctuating state of impatience, wonderment and partial gratification. We are held this way until the final moment of closure' (57). Therefore, although the very specific fragmentation of television narrative offers us multiple stops, questions and intermediate rewards (episodes, hiatuses and seasons), we do not understand the full meaning until the initial conflict, which launches the series and structures the narrative, is definitively resolved. 
Pre-copy-edited version of "Moral Emotions, Antiheroes and the Limits of Allegiance", in Emotions in Contemporary TV Series, García, Alberto N. (eds), Palgrave McMillan, Basingstoke, 2016, pp. 52-70. (See Springer website)

In a television landscape where the story is becoming ever more sophisticated, one of the great advances of 'complex TV' regards the 'ars moriendi' (Harrington) of audiovisual fictions: the end of the series increasingly aims for circularity, emotional climax, reasonable surprise and internal narrative coherence. This means that, in series where the antihero has lost public favour, the series finale is the key to recovering the sympathetic allegiance of the viewer a posteriori, even strictly post-mortem in certain cases. This possibility of recovering a viewer's allegiance post-mortem has an extra importance in television fiction: it implies that text that has been open to fluctuations and interpretations for years ('serial articulation' in Mittel's terms) decides to clearly mark its border, that is, to try to stabilise a 'structure of sympathy' that has until now been oscillating.

Therefore, before dying while contemplating, with a smile, the laboratory where his 'work of art' - the blue methamphetamine — was produced, the fugitive, Walter White, says goodbye to Skyler and their children: 'I did it for me. I liked it. I was good at it and I was really ... I was alive'; he admits this with a mixture of pride and sadness. His apology in 'Felina' (5.16) is necessary as the first step to fully restoring our allegiance. Together with that scene, and without denying the moral complexity of his last conversation with Skyler and the scene where he caresses his sleeping daughter, Holly, Walter admits his selfishness and the price to be paid for his sins while seeking forgiveness from the ones to whom he has done the most damage; the closing of the storyline after releasing Jesse and liquidating the Nazis provides a perverse kind of happy ending, in accordance with the moral sympathy demanded of the viewer. Walter pays for his sins, not only through the loss of the family he intended to save, but with the loss of his own life. Still, there were those who criticised the final result precisely for being complacent and for not being difficult enough for Walter, confirming the 
Pre-copy-edited version of "Moral Emotions, Antiheroes and the Limits of Allegiance", in Emotions in Contemporary TV Series, García, Alberto N. (eds), Palgrave McMillan, Basingstoke, 2016, pp. 52-70. (See Springer website)

fragility of viewer allegiance to Walter White. That is, there were many viewers who not only wanted Walter to die violently, as finally happens, but to fail completely in his desire for revenge and restitution of the order his own chaos had generated (Nussbaum).

The series finale of The Shield, one of the most acclaimed final episodes in television history, is constructed on a similar ambiguity. While Vic Mackey wins his last battle, he loses everything that justified his actions: his family and his badge. His defeat is highlighted with silence and a series of frigid, closed final shots, which stand counter to the electricity of the shots normally employed throughout the series. In that cold, mechanical and monotonous cubicle, with that cheap suit that makes him look like a puppet, the omnipotent and spirited Vic Mackey seems condemned to a living death, after all the pain he has caused his loved ones.

In both series, however, the sad fate of its protagonists - pure poetic justiceallows the recovery, a posteriori, of our allegiance to them; we see them pay for their crimes, for the harm they have caused, and this restores the comprehensive moral framework we established with them throughout the series and, also, a sizeable proportion of our moral sympathy towards them. We see them in a different light when we realise — in a twisted remembrance from the classic film noir motto 'crime doesn't pay' - that in the grey, dark area where these narratives takes place, ambivalent good triumphs over defensible evil and conflicted sinners pay for their sometimes-justified sins.

\section{Conclusion}

'When Mima talked about you, I couldn't tell if it was love or hate' is one of the last sentences Nucky Thompson hears in Boardwalk Empire ('ElDorado', 5.8) As spectators, we need to wait until the last parallel editing - the final minute - of the 
whole series to fully realise who Nucky was and why he has been acting like a truly contradictory antihero over the five seasons. The characteristics discussed during this essay demonstrate how our moral evaluation is influenced, even manipulated, by the emotional relationship that TV series establishes for us as spectators. 'Do we feel an allegiance with — a sympathy for - a character because of the perverse act that they engage in or in spite of that act?' asks Smith ('Gangsters, Cannibals' 223).

The serial format allows us to constantly revisit our dilemma between because of and the in spite of, aware that the dramatic engine of many of these series proceeds from an irresolvable contradiction that the television story itself brings to the fore again and again. As evidenced by the many examples given, the sympathetic allegiance that characterises series starring antiheroes has its limits, to the point that it can move radically from one character to another during the story. Therefore, as we have tried to show, strategies of 'cyclical re-allegiance' are necessary in order to continue feeding the emotional and moral tension of television stories, right up to the very close of the series' finale.

\section{Works Cited}

Abbott, H. Porter. The Cambridge Introduction to Narrative. Cambridge; New York: Cambridge University Press, 2008. Print.

Blanchet, Robert, and Margrethe Bruun Vaage. "Don, Peggy, and Other Fictional Friends? Engaging with Characters in Television Series." Projections: The Journal for Movies and Mind 6.2 (2012): 18-41. Print.

Carroll, Noël. Engaging the Moving Image. New Haven: Yale University Press, 2003. Print.

---. "Film, Emotion, and Genre." Passionate Views: Film, Cognition, and Emotion. Eds. Carl R. Plantinga and Greg M. Smith. Baltimore; London: Johns Hopkins University Press, 1999. 21-47. Print. 
Pre-copy-edited version of "Moral Emotions, Antiheroes and the Limits of Allegiance", in Emotions in Contemporary TV Series, García, Alberto N. (eds), Palgrave McMillan, Basingstoke, 2016, pp. 52-70.

(See Springer website)

---. "Movies, the Moral Emotions, and Sympathy." Midwest Studies In Philosophy 34.1 (2010): 1-19. Print.

---. The Philosophy of Horror Or Paradoxes of the Heart. New York: Routledge, 1990. Print.

---. "Sympathy for the Devil." The Sopranos and Philosophy: I Kill therefore Ia Am. Eds. Richard Greene and Peter Vernezze. Chicago: Open Court, 2004. 121-136. Print.

Creeber, Glen. Serial Television: Big Drama on the Small Screen. London: BFI Publ, 2004. Print.

Donnelly, Ashley M. Renegade Hero Or Faux Rogue: The Secret Traditionalism of Television Bad Boys. Jefferson, North Carolina: McFarland, 2014. Print.

Eaton, AW. "Robust Immoralism." The Journal of Aesthetics and Art Criticism 70.3 (2012): 281-92. Print.

Echart, Pablo, and Alberto N. García. "'Round the Decay / of that Colossal Wreck': Pride and Guilt as Narrative Emotions." The Methods of Breaking Bad. Eds. Jacob Blevins and Dafydd Wood. Jefferson: McFarland, 2014. 78-93. Print.

Frye, Northrop. Educated Imagination and Other Writings on Critical Theory, 19331962. Toronto: University of Toronto Press, 2006. Print.

Gaut, Berys. "Identification and Emotion in Narrative Film." Passionate Views: Film, Cognition, and Emotion. Eds. Carl R. Plantinga and Greg M. Smith. Baltimore; London: Johns Hopkins University Press, 1999. 200-216. Print.

Genette, Gérard. Nouveau Discours Du Récit. Paris: Seuil, 1983. Print.

Grodal, Torben Kragh. Moving Pictures: A New Theory of Film Genres, Feelings and Cognition. Oxford: Clarendon Press, 1997. Print.

Harrington, C. L. "The Ars Moriendi of US Serial Television: Towards a Good Textual Death.” International Journal of Cultural Studies 16.6 (2013): 579-95. Print.

Keen, Suzanne. “A Theory of Narrative Empathy." Narrative 14.3 (2006): 207-36. Print.

Kermode, Frank. The Sense of an Ending: Studies in the Theory of Fiction. London; Oxford; New York: Oxford University Press, 1967. Print.

Lewis, Michael J. "Making Modern Evil: Terrorism, Torture, and the Creation of Evil in 24." Vader, Voldemort and Other Villains: Essays on Evil in Popular Media. Ed. Jamey Heit. Jefferson: McFarland, 2011. 162-174. Print. 
Pre-copy-edited version of "Moral Emotions, Antiheroes and the Limits of Allegiance", in Emotions in Contemporary TV Series, García, Alberto N. (eds), Palgrave McMillan, Basingstoke, 2016, pp. 52-70.

(See Springer website)

Lindsay-Hartz, Janice, Joseph de Rivera, and Michael F. Mascolo. "Differentiating Guilt and Shame and their Effects on Motivation." Self-Conscious Emotions: The Psychology of Shame, Guilt, Embarrassment, and Pride. Eds. June Price Tangney and Kurt W. Fischer. New York: Guilford Press, 1995. 274-300. Print.

Lotz, Amanda D. Cable Guys: Television and Masculinities in the 21st Century. New York: NYU Press, 2014. Print.

Martin, Brett. Difficult Men: Behind the Scenes of a Creative Revolution: From the Sopranos and the Wire to Mad Men and Breaking Bad. New York: The Penguin Press, 2013. Print.

McCaw, Neil. "The Ambiguity of Evil in TV Detective Fiction." Inside \& Outside of the Law: Perspectives on Evil, Law \& the State. Eds. Shubhankar Dam and Johathan Hall. Oxford: Inter-Disciplinary Press, 2009. 21-29. Print.

Mittell, Jason. Complex TV: The Poetics of Contemporary Television Storytelling (prepublication edition). 2012-13. Web. <http://mcpress.mediacommons.org/complextelevision/>.

Neill, Alex. "Empathy and (Film) Fiction." Post-Theory. Reconstucting Film Studies. Eds. Noël Carroll and David Bordwell. Madison: University of Wisconsin Press, 1996. 175-194. Print.

Nelson, Robin. State of Play: Contemporary "High-End” TV Drama. Manchester; New York: Manchester University Press, 2007. Print.

Nussbaum, Emily. “The Closure-Happy 'Breaking Bad' Finale.” The New Yorker. 30th September 2013. Web. <http://www.newyorker.com/culture/culture-desk/theclosure-happy-breaking-bad-finale>.

Pérez, Xavier. "Las edades de la serialidad." La balsa de la Medusa 6 (2011): 13-30. Print.

Plantinga, Carl. "I Followed the Rules, and they all Loved You More': Moral Judgment and Attitudes Toward Fictional Characters in Film." Midwest Studies in Philosophy 34.1 (2010): 34-51. Print.

---. "The Scene of Empathy and the Human Face in Film." Passionate Views: Film, Cognition, and Emotion. Eds. Carl R. Plantinga and Greg M. Smith. Baltimore; London: Johns Hopkins University Press, 1999. 239-256. Print.

Shafer, Daniel M., and Arthur A. Raney. "Exploring how we Enjoy Antihero Narratives." Journal of Communication 62.6 (2012): 1028-46. Print. 
Pre-copy-edited version of "Moral Emotions, Antiheroes and the Limits of Allegiance", in Emotions in Contemporary TV Series, García, Alberto N. (eds), Palgrave McMillan, Basingstoke, 2016, pp. 52-70.

(See Springer website)

Smith, Murray. Engaging Characters: Fiction, Emotion, and the Cinema. Oxford: Clarendon Press, 1995. Print.

---. “Gangsters, Cannibals, Aesthetes, Or Apparently Perverse Allegiances.” Passionate Views: Film, Cognition, and Emotion. Eds. Carl R. Plantinga and Greg M. Smith. Baltimore; London: Johns Hopkins University Press, 1999. 217-238. Print.

---. "Just what is it that Makes Tony Soprano such an Appealing, Attractive Murderer?" Eds. Ward E. Jones and Samantha Vice. Oxford: Oxford University Press, 2011. 66-90. Print.

Tan, Ed S. Emotion and the Structure of Narrative Film: Film as an Emotion Machine. Mahwah: Erlbaum, 1996. Print.

Vaage, Margrethe Bruun. The Antihero in American Television. Routledge, Forthcoming. Print.

---. "Blinded by Familiarity: Partiality, Morality, and Engagement in Television Series." Cognitive Media Theory. Eds. Ted Nannicelli and Paul Taberham. New York: Routledge, 2014. 268-284. Print.

---. "Fiction Film and the Varieties of Empathic Engagement." Midwest Studies in Philosophy 34.1 (2010): 158-79. Print.

---. "Fictional Reliefs and Reality Checks." Screen 54.2 (2013): 218-37. Print.

---. "Self-Reflection.” Nordicom Review 30.2 (2009): 159-78. Print.

Von Moltke, Johannes. "Sympathy for the Devil: Cinema, History, and the Politics of Emotion.” New German Critique 34.3 (2007): 17-44. Print.

Zoller Seitz, Matt. "Seitz on Breaking Bad, and Why Viewers Need to Whitewash Walter White." Vulture. 18th September $2013 . \quad$ Web. <http://www.vulture.com/2013/09/seitz-breaking-bad-walter-white-apologistsphone-call.html>. 